\title{
Study on Relationship between Visitor Value, Degree of Satisfaction and Loyalty in Musical Festival Activity
}

\author{
Cheng-Wei Chung1,2 \\ ${ }^{1}$ Department of Leisure and Tourism Management, Shu-Te University, Kaohsiung County, Chinese Taipei \\ ${ }^{2}$ Department of Industrial Technology Education, National Kaohsiung Normal University, Kaohsiung County, \\ Chinese Taipei \\ Email: alexccw@stu.edu.tw
}

Received 17 September 2014; revised 15 October 2014; accepted 12 November 2014

Copyright (c) 2014 by author and Scientific Research Publishing Inc.

This work is licensed under the Creative Commons Attribution International License (CC BY). http://creativecommons.org/licenses/by/4.0/

(c) ()

\begin{abstract}
Compared with other types of festival activities, the musical festivals can attract large crowds of visitors easily and quickly. When the value experience of visitors is high, their satisfaction and loyalty will also be higher. In activities, the high degree of satisfaction means higher loyalty. The hypothesis model in this study indicates the causal relationship between visitor value and degree of satisfaction, as well as the significant impact of visitor value on loyalty in musical festival activities. However, though the musical festival activities can attract visitor stream very quickly, the activity organizers should think more about how to make the visitors willing to come, especially when most visitors for these activities make a special trip. For these visitors, the degree of experience of the visitors should be emphasized, because this will be the most important reason influencing visitors' feeling about the activities.
\end{abstract}

\section{Keywords}

Festival, Visitors Value, Satisfaction, Loyalty

\section{Introduction}

At the end of the $20^{\text {th }}$ century, the declining of local manufacturing industry and the transformation of industry structure brought a large variety of modern festival activities in Taiwan, which established the city image and infused inherent vitality for the development and transformation of the city. Festival activities share one common point that they are all short-term activities held by some organizations with plans [1]. [2] suggested that 
celebrations are celebrative activities with certain themes and open to the public, generally covering artistic, musical, literature and art, culture, folk activity, sport, anniversary, combination of tradition and modern type. Musical festival activities, as combination of personal musical performance and creation and the local feature, are held by the county governments and serve as one of the policies to elevate the local economical industry. This cross domain combination of cultural creative industry and tourism industry not only industrializes the cultural creation in Taiwan, but also makes the festival activities drive the industry upgrade and transformation [3]. Based on the above research motives, this study takes the 2013 Hualien Summer Festival as the target, and proposes the following four research purposes: 1) To establish the relationship model between visitor motivation, value, degree of satisfaction and loyalty of visitors in musical festival activities; 2) To explore the difference in motivation, value, degree of satisfaction and cognition caused by different visitor property; 3) To explore the impact and change of motivation, value, degree of satisfaction and loyalty, with the visitor property as the moderator variable.

\section{Literature Review}

\subsection{Festival Activity}

Festival activity refers to an open short-term regional activity with certain theme or culture, which is mainly aimed at establishing the positive images of the region. The time can be distinguished by different seasons, vacations and industries [4]. [5] defined festival activity as a kind of special activity occurring once or often with the organization and business sponsorship, except routine activities. He held that such activities should cover dance, films, music, art, carving, native cultural heritage, sports events and seasonal ritual.

\subsection{Definition and Measurement of Visitor Value, Degree of Satisfaction and Loyalty}

Value is a kind of conviction and idea of human beings, is the product of subjective and objective comparison and judgment and careful reflection. [6] discussed the visitor value, degree of satisfaction and loyalty of visitors in lantern shows, and found that the previous study subjects were mostly perceived value or experience value. After interviews, Li established the visitor value scale with five dimensions, respectively 1) functional value; 2) emotional value; 3) social value; 4) epistemic value; 5) conditional value. Degree of satisfaction is a tool used to measure people's cognition about product, service, job, community, life quality or outdoor recreation quality [7]. [8] indicated that leisure activity participants can paint pictures, play music or dance in the natural scenes and draw satisfaction from the enriched mind. In brief, the degree of satisfaction is the degree in which individuals acquire satisfaction of personal requirements from experience. Reviewed previous literature published over the recent decade, and confirmed the ideal model of visitor degree of satisfaction. They also verified the relationship between visitor degree of satisfaction and loyalty. As the antecedent variable of loyalty, degree of satisfaction not only exerts direct impact on loyalty, but is also influenced by visitor value, as the intermediary agent [6] [9]. [10] suggested that loyalty concept comprises of two parts, behavior and attitude. Behavior refers to the times visitors participate in particular activities, facilities and receive service, exhibiting the consistency between the many times of participation by the visitors. [11] proposed the four stages of customer loyalty, which differ in strength, namely cognitive loyalty, emotional loyalty, intended loyalty and behavioral loyalty. He also pointed out that the loyal behaviors in these stages vary a lot. [12] studied consumer background, and concluded that the degree of satisfaction, trust, cognitive value is antecedent variable of customer loyalty. To sum up, the loyalty of visitors is influenced by visitor value and degree of satisfaction.

\section{Method}

\subsection{Research Structure}

This study explores the relationship between visitor value, degree of satisfaction and loyalty. The conceptual framework of this study on which the empirical analysis is based is concluded from literature review.

\subsection{Research Hypotheses}

The literature review and research framework reveal that the visitor value exerts impact on degree of satisfaction and loyalty. The research hypotheses are proposed (Figure 1): 


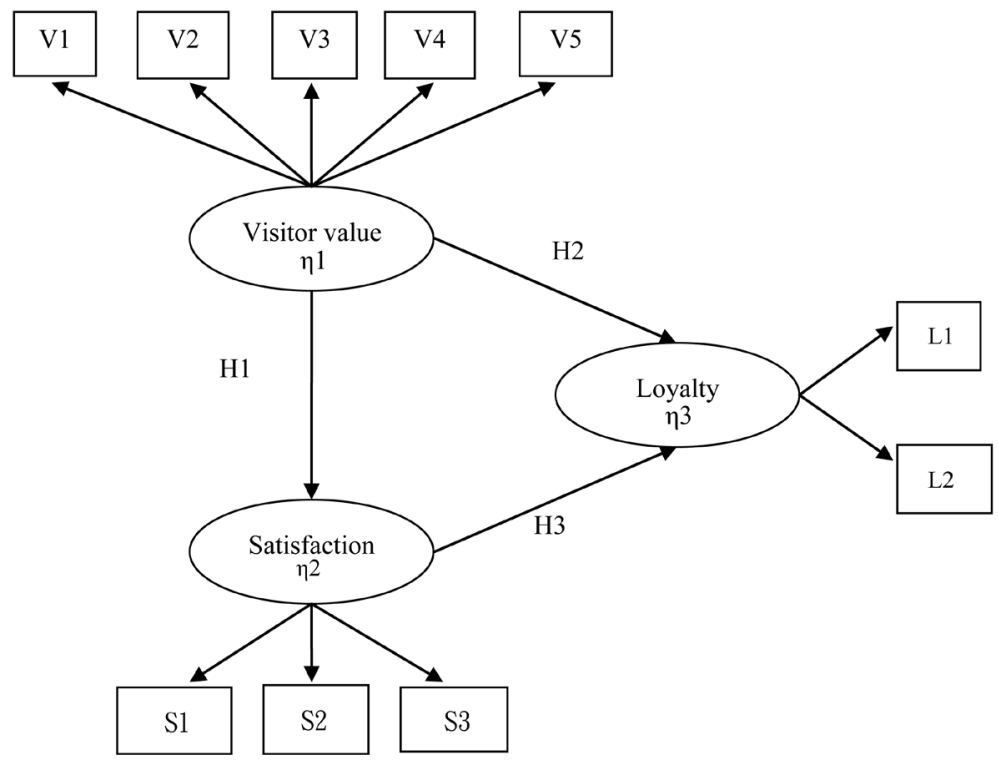

Figure 1. The structure of research.

H1: The visitor value has a significant positive impact on degree of satisfaction.

$\mathrm{H} 2$ : The visitor value has a significant positive impact on loyalty.

H3: The degree of satisfaction has a significant positive impact on loyalty.

\subsection{Research Subjects and Sampling}

This study takes the eight-day long 2013 Hualien Summer Festival held in Hualien County in 2013 as the target, and the participating visitors as the subjects. Next to Pass technique [13] is adopted in the study. When the population sample is between 500,000 and $\infty$ inquired from the comparison table of tolerable error and sample size within the $99 \%$ confidence interval, the tolerable error is within $\pm 4 \%$. According to the calculation result, 1035 questionnaires should be distributed. This study thus distributed 1200 questionnaires to ensure the survey accuracy.

\section{Results Analysis}

\subsection{Descriptive Statistic Analysis of Socio-Economic Background and Travel Features of Visitors}

The descriptive statistic analysis is carried out on the personal information of the visitors, including gender, age, marital status, profession, residence, educational status, available amount. As for socio-economic background, most visitors are female (64.1\%), young adults of 20 years old or below (36.2\%), followed by 21 - 30 years old (26.2\%), single (no children) (72.0\%), students (551, 49.1\%), have university (junior college) background (42.9\%), live in Hualien County (native) (68.5\%), and have no recurring income (39.5\%). As for travel attributes, descriptive statistic analysis is carried out on the two items, whether browsing the official website (single selection) and whether participating by special trips or passing by (single selection). The item concerning browsing the official websites is mainly to probe into the degree in which the visitors of the musical festival activities understand internet information. Those who chose "Yes" account for 53.8\%. It can be inferred that the visitors in musical festival activities have the desire to know the performance time of their favorite singers, so they can for search more information on the internet compared with visitors of other festival activities and they stay for the relatively shorter time. The item of by special trips or passing by is designed to know how many visitors participate in the activity by making special trips, whose number accounts for $86.2 \%$ in the statistical results. This shows that 2013 Hualien Summer Festival is an activity that can attract people to participate, so it is representative enough to be the subject of the study. 


\subsection{Pearson Product-Moment Correlation Analysis and Reliability Analysis}

Pearson product-moment correlation analysis was conducted to explore whether there is significant correlation between visitor value, degree of satisfaction and loyalty. This study also examined whether the variables of these dimensions reach the expected significance by one tailed significance test based on the hypothesis direction. The correlation analysis of the variables of visitor value, degree of satisfaction and loyalty is shown as in Table $\mathbf{1 .}$ The visitor value is in positive correlation to loyalty and degree of satisfaction. The degree of satisfaction positively relates to loyalty. The value of the scale Cronbach's Alpha is between 0.835 and 0.974 , indicating that the scale dimensions all have relatively high reliability, i.e. the survey scale has good internal consistency.

\subsection{Verification Analysis of SEM Structural Equation Modeling}

In equilibrium model analysis, it is necessary to first examine the fitness degree of the model, and then analyze the conformity between the hypothetical model and the observed material by fitness degree index calculation. [14] evaluated the degree of adaptation of the model in reference to NFI, NNFI, CFI, IFI not easily influenced by the sample size, and examined whether the fitness degree of the model reached the acceptable scope. In this study, value-added adapter pointer projects are respectively NFI $=0.98$, NNFI $=0.97$, CFI $=0.98$, IFI $=0.98$, RFI $=0.97$, conforming to the standard of higher than 0.9 . The $\lambda$ value estimated from observational variables and latent variables all reach significant level.

\subsection{Estimation Results of Model Parameters}

The overall model diagram concerning visitor value, degree of satisfaction and loyalty established in this study is shown in Figure 2. The causal relationship between each dimension and variable analyzed on the basis of the parameter estimation by means of SEM structural equation modeling is shown in Table 2.

\section{Acknowledgements}

According to the empirical results analysis in this study, the visitor value has a significant positive impact on loyalty and degree of satisfaction (H1) (H3). The degree of satisfaction has a significant positive impact on loyalty (H3). The results are consistent with [6]. However, empirical results indicate that the leisure motivation of visitors has no significant impact on loyalty, which is consistent with [15]. This confirms that only in situ experience can elevate the loyalty in festival activities. In recent years, musical festival activities have received increasing emphasis. Whether for the countdown party, Spring Scream, or Hohaiyan Rock Festival, they all show that these kinds of activities are the favorite of visitors. Compared with other types of festival activities, the

Table 1. Correlation analysis and reliability analysis of visitor value, degree of satisfaction and loyalty.

\begin{tabular}{cccc}
\hline & Visitors value & Satisfaction & Loyalty \\
\hline Visitors value & $1 / 0.969$ & & \\
Satisfaction & $0.626^{* *}$ & $1 / 0.955$ & \\
Loyalty & $0.440^{* *}$ & $0.496^{* *}$ & $1 / 0.835$ \\
\hline Note: $^{*} p<0.05 \cdot{ }^{* *} p<0.01$ & & &
\end{tabular}

Table 2. Recapitulation statement of causal relationship parameter estimation between latent variable.

\begin{tabular}{cccc}
\hline Parameter & Estimating Value & Error Variance & $\mathbf{R}^{2}$ \\
\hline$\gamma$ SA.VV & $0.26(\mathrm{t}=5.52)$ & $0.44(\mathrm{t}=16.39)$ & 0.56 \\
$\gamma$ LO.VV & $0.14(\mathrm{t}=2.43)$ & & \\
$\beta$ LO.SA & $0.42(\mathrm{t}=8.52)$ & $0.65(\mathrm{t}=13.55)$ & 0.35 \\
\hline
\end{tabular}

Note: * indicates reaching significant level $p<0.05$, t $>1.96$. 


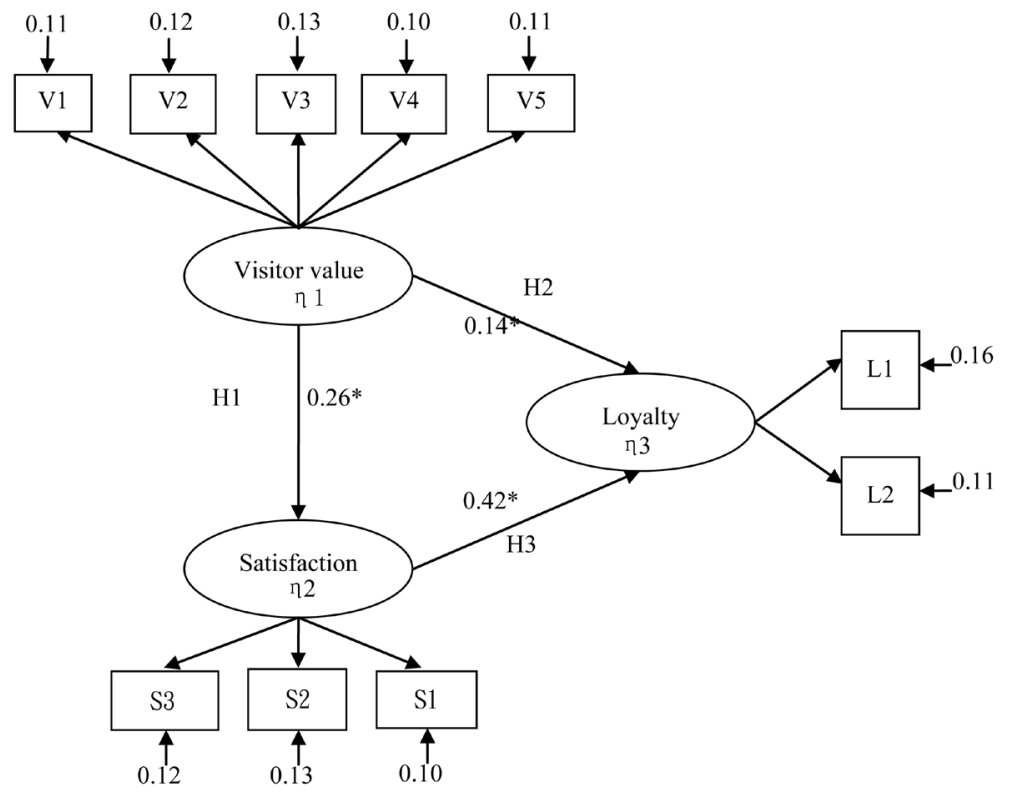

Figure 2. Structural equation model.

musical ones can attract visitor stream more easily and quickly. However, although the musical festival activities can attract crowds quickly, the activity organizers should think more about how to enhance the visiting intention, especially when most visitors for these activities make a special trip. For these visitors, the degree of experience of the visitors, rather than their motivation, should be emphasized, because this will be the most important reason influencing visitors' feeling about the activities.

\section{References}

[1] Walsh, H.J. and Stevens, T. (1990) The Management of Visitor Attractions and Events. Prentice Hall, Englewood Cliffs.

[2] Richards, R.A. (1992) The Effect of Dwarfing Genes in Spring Wheat in Dry Environments. II. Growth, Water Use and Water-Use Efficiency. Crop and Pasture Science, 43, 529-539. http://dx.doi.org/10.1071/AR9920529

[3] Huang, C.Y. (2010) Cultural and Creative Energy Combined with Tourism Festival-Music Festival. Taiwan Economic Research Monthly, 33, 46-52.

[4] Cheng, C.W., Chen, H.T. and Tu, H.Y. (2012) The Study of Conduct Characteristics Index to Locality Festival Sustainable Development. Journal of Sport, Leisure and Hospitality Research, 7, 45-64.

[5] Getz, D. (1991) Festivals, Special Events, and Tourism. Van Nostrand Reinhold, New York.

[6] Li, C.J. (2012) Constructing and Verifying the Values Scales for Festival Visitors: The Example of Central Taiwan Lantern Festival. Kaohsiung Normal University Journal, 32, 91-112.

[7] Hou, J.S. and Yao, C.W. (1997) Residents' Attitude of Leisure and Satisfaction of Neighborhood Park in Taichung City. Journal of Outdoor Recreation Study, 10, 1-17.

[8] Bammel, G. and Burrus-Bammel, L.L. (1996) Leisure and Human Behavior. 3rd Edition, Times Mirror Higher Education Group. William C. Brown, Dubuque.

[9] Fang, C.Y., Lee, M.T. and Tsai, C.C. (2011) An Examination of the Effects of Motivation and Satisfaction on Loyalty: National Museum of Marine Biology and Aquarium. Bulletin of Taiwan Shoufu University, 2, 55-74.

[10] Backman, S.J. and Crompton, J.L. (1991) The Usefulness of Selected Variables for Predicting Activity Loyalty. Leisure Sciences, 13, 205-220. http://dx.doi.org/10.1080/01490409109513138

[11] Oliver, R.L. (1980) A Cognitive Model of the Antecedents and Consequences of Satisfaction Decisions. Journal of Marketing Research, 17, 460-469. http://dx.doi.org/10.2307/3150499

[12] Agustin, C. and Singh, J. (2005) Curvilinear Effects of Consumer Loyalty Determinants in Relational Exchanges. Journal of Marketing Research, 42, 96-108. http://dx.doi.org/10.1509/jmkr.42.1.96.56961

[13] Tsaur, S.H., Chiu, Y.T. and Wang, C.H. (2007) The Visitors Behavioral Consequences of Experiential Marketing: An 
Empirical Study on Taipei Zoo. Journal of Travel and Tourism Marketing, 21, 47-64. http://dx.doi.org/10.1300/J073v21n01_04

[14] Ping, L.Y. (2004) The Study of Developing Teacher Personality Inventory for Elementary School Teachers. Journal of National University of Tainan, 38, 115-130.

[15] Cheng, C.W., Lung, C.H. and Chang, C.W. (2013) A Study on Leisure Motivation, Visitors' Value, Satisfaction and Loyalty for Visitor-A Case of 2013 Kaohsiung International Invitational Dragon Boat Race. Journal of Sport and Recreation Management, 10, 45-62. 
Scientific Research Publishing (SCIRP) is one of the largest Open Access journal publishers. It is currently publishing more than 200 open access, online, peer-reviewed journals covering a wide range of academic disciplines. SCIRP serves the worldwide academic communities and contributes to the progress and application of science with its publication.

Other selected journals from SCIRP are listed as below. Submit your manuscript to us via either submit@scirp.org or Online Submission Portal.
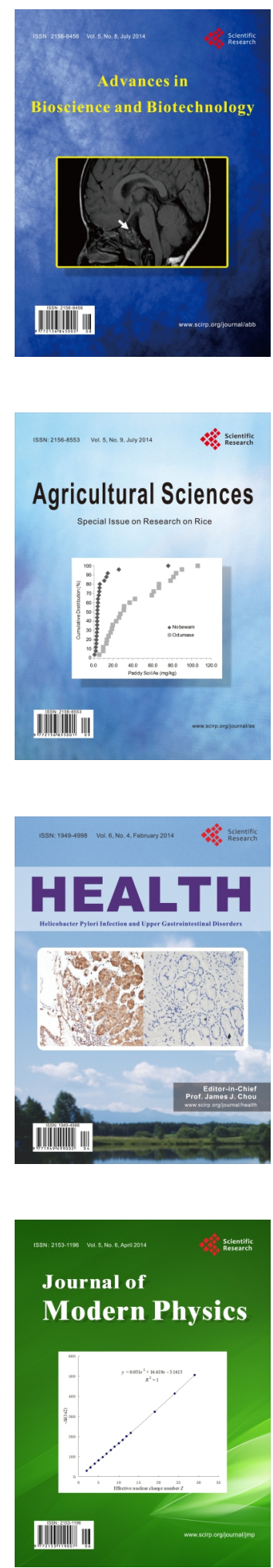
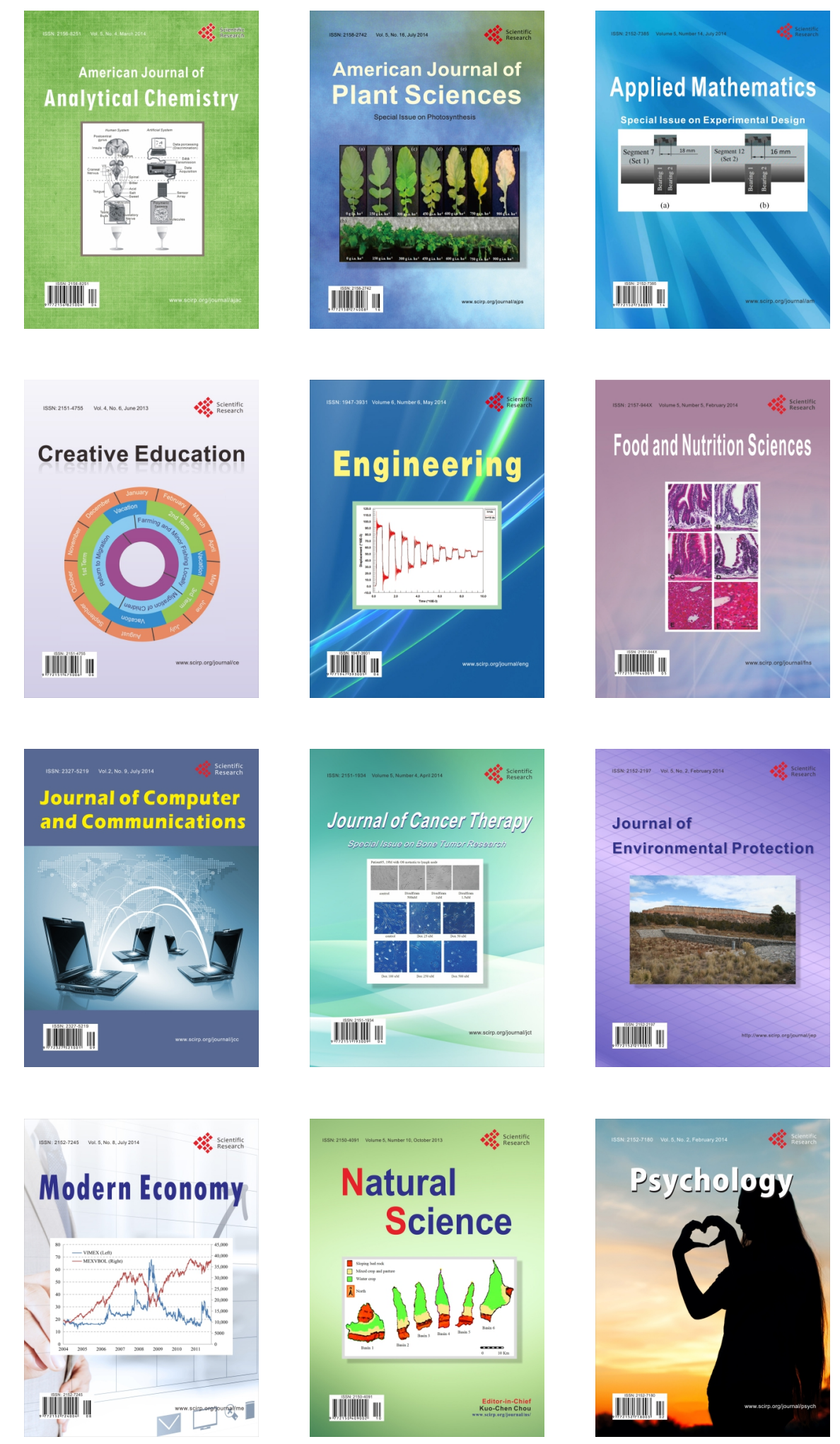